УДК: 629.4:681.518.5

МАРТИНОВ I. Е., доктор технічних наук, професор, НЕЙЧЕВ О. В., кандидат технічних наук, доцент, СОСУНОВ О. О., кандидат технічних наук, доцент, ПЕТУХОВ В. М., кандидат технічних наук, доцент, ТРУФАНОВА А. В., кандидат технічних наук, доцент (Український державний університет залізничного транспорту)

\title{
Система теплового контролю буксових вузлів рухомого складу
}

\begin{abstract}
Запропоновано систему теплового контролю буксових вузлів рухомого складу, щзо здатна суттєво підвищити ефективність контролю ходових частин вагонів $і$ локомотивів за рахунок використання декількох каналів вимірювання температури зовнішніх поверхонь кожного буксового вузла, маточин коліс $i$ введення 8 систему більш повної початкової інформації, на підставі якої приймається рімення про фактичний стан буксових підиипників.
\end{abstract}

Ключові слова: система контролю стану буксових вузлів рухомого складу, система діагностування рухомого складу, тепловий контроль буксових вузлів.

\begin{abstract}
Вступ
Одним 3 найбільш $\quad$ відповідальних конструкції вантажного вагона $є$ буксові вузли 3 роликовими підшипниками. Як показує багаторічний досвід експлуатації парку вантажних вагонів України, саме буксові вузли через надмірний нагрів за період 1995-2017 рр. спричинили 3066 випадків відчеплень вагонів на шляху прямування. При цьому додатково приладами дистанційного контролю колісних пар та оглядачами вагонів за зовнішніми ознаками було виявлено відмови буксових вузлів, які створювали загрозу безпеці руху (2014 р. - 1109 випадків, 2015 р. 1538, 2016 р. -1571, 2017 р. - 1542 відповідно) [1].

Рухомий склад нового покоління згідно 3 вимогами "Комплексної програми оновлення залізничного рухомого складу України на 2008-2020 роки" має забезпечити збільшення терміну служби вагона, його основних деталей та вузлів в 1,5-2 рази у порівнянні з вагонами застарілих зразків. При цьому планується досягти збільшення міжремонтного пробігу основних несучих деталей i вузлів, у т. ч. вагонних буксових підшипників до 1 млн км. Однак очевидно, що навіть за умови зменшення інтенсивності відмов буксових вузлів вплив їх стану на безпеку руху потребує безперервного вдосконалення чинних методів і засобів контролю букс і створення нових, які б задовольняли сучасні вимоги експлуатації.
\end{abstract}

\footnotetext{
Аналіз останніх досліджень і публікацій

Проблемам апаратурного контролю рухомого складу у процесі руху присвячено значну кількість як наукових праць, зокрема [2-9], так i технічних розробок [10-14]. 3 аналізу вказаних джерел випливає,
}

що розвиток сучасних технологій контролю технічного стану рухомого складу відбувається за декількома напрямками: шляхом створення систем контролю поверхні та параметрів кочення коліс, відеоконтролю геометричних параметрів елементів рухомого складу, температурного (теплового) контролю букс та гальм, акустичного аналізу, контролю наявності деталей, що волочаться, тощо [15]. Найбільш поширеними 3 наведеного переліку, зокрема на залізницях України, є системи теплового контролю буксових вузлів. Саме питанням вдосконалення систем подібного типу i присвячено статтю.

При безконтактній діагностиці за рівнем нагріву зовнішніх поверхонь буксових вузлів і дисків коліс важливим моментом $\epsilon$ те, які деталі буксового вузла потрапляють у зону сканування приймача інфрачервоного (ІЧ) випромінювання, розташованого в спеціальній прирейковій камері, розміщеній біля рейки або на рейці. У більшості відомих систем діагностики (наприклад, ПОНАБ, ДИСК, КТСМ, АСДК-Б) прирейкова камера (ПК) та інфрачервоний приймач не можуть змінювати своє положення в просторі і тим самим орієнтацію приймача залежно від типу рухомого складу, що проходить. Тому в умовах експлуатації приймач ІЧ випромінювання орієнтується таким чином, щоб сканування букс здійснювалося для максимальної кількості конструкцій і по найбільш інформативних зонах (зони максимального відображення температури підшипника).

(근. Е. Мартинов, О. В. Нейчев, О. О. Сосунов, В. М. Петухов, А. В. Труфанова, 2018 
Недоліком систем діагностики подібного типу є те, що сканування букси здійснюється поодиноким вузьконаправленим приймачем ІЧ випромінювання складною просторовою траєкторією. Від того, які зони корпусу букси потраплять у зону огляду і під яким кутом, залежить рівень потужності випромінювання, що приймається, і рівень сигналу, на підставі якого приймається рішення про температуру підшипника, відповідно. Тому навіть незначний вихід істинної траєкторії сканування на іншу поверхню корпусу букси призводить до формування неточного або хибного сигналу.

Одним із шляхів вирішення вказаної проблеми може бути сканування контрольованої поверхні рухомою оптичною системою прирейкової камери або нерухомим ІЧ приймачем i рухомим у площині, перпендикулярній до повздовжньої осі колії, дзеркалом [12]. Відбитий дзеркалом потік ІЧ випромінювання фокусується оптичною системою на активній поверхні приймача, де перетворюється в електричні сигнали, пропорційні температурі контрольованих поверхонь. Система діагностики, що функціонує $з$ використанням вказаного принципу, дає змогу сформувати більш інформативний масив даних про розподіл температур нижньої поверхні корпусу букси, порівняно із системами 3 нерухомою оптикою, однак наявність у складі підсистеми сканування вузлів, схильних до механічного зносу, є суттєвим недоліком. Крім того, у разі зміни параметрів приймача IЧ випромінювання (наприклад, внаслідок старіння) існує вірогідність пропускання аварійних букс або формування хибних сигналів тривоги.

Слід зазначити, що загальним недоліком усіх відомих систем діагностики буксових вузлів рухомого складу є відсутність резервування пристроїв системи, у тому числі і тих, некоректне функціонування яких може призвести до небезпечних відмов - пропусків аварійних букс.

Вочевидь, що для більш якісного контролю параметрів буксових вузлів і маточин коліс у складі ПК має бути декілька приймачів ІЧ випромінювання: 3 однаковою просторовою орієнтацією для дублювання один одного i/або таких, що мають різну орієнтацію для вимірювання температур декількох точок на поверхні контрольованих вузлів. Проте через значні габарити приймальних пристроїв ІЧ випромінювання, до складу яких входять власне приймач, лінзовий комплект, корпус, елементи кріплення, візирування тощо, при розміщенні декількох приймачів в одній ПК суттєво збільшуються габарити і маса прирейкових камер, ускладнюється процес їх орієнтації, термостатування, стробування зон контролю.

\section{Основна частина}

3 метою усунення перелічених вище недоліків пропонується система діагностики буксових вузлів рухомого складу, яка здатна контролювати температуру нагріву декількох точок зовнішніх поверхонь корпусів букс і маточин коліс 3 кожного боку поїзда i формувати комплексну картину розподілу температур нагріву контрольованої поверхні (поверхонь) [13]. Така можливість виникає внаслідок розосередження елементів/пристроїв апаратури приймально-підсилювального тракту кожного вимірювального каналу. В запропонованій системі ПК містять по $\mathrm{N}$ лінзових комплектів приймальної оптики, сполучених за допомогою прозорих для IЧ випромінювання оптоволоконних світловодів 3 приймачами ІЧ випромінювання. Причому приймачі ІЧ випромінювання розташовуються на посту. Тобто у прирейкових камерах встановлюються лише лінзові комплекти 3 елементами кріплення, а отриманий ними у процесі контролю «корисний» сигнал надходить до приймачів-перетворювачів оптоволоконними світловодами. Враховуючи незначні розміри лінзових комплектів у порівнянні 3 розмірами приймальних капсул (ПОНАБ, ДИСК) або приладових відсіків (АСДК-Б), у прийнятних габаритах камер можливе розміщення декількох таких комплектів. У випадку розташування у прирейкових камерах одного ЛК (або двох - для резервування) можна суттєво зменшити габарити ПК із перспективою їх встановлення усередині колії і орієнтацією на інші вузли рухомого складу.

Розміщення приймачів ІЧ випромінювання в умовах поста послаблює вимоги до їх розмірів, конструктивного оформлення, полегшує оптимізацію температурних режимів роботи і сприяє підвищенню точності вимірювання температури контрольованої поверхні. Оскільки в умовах поста рівень динамічних і акустичних навантажень істотно нижчий, ніж в умовах прирейкової камери, виникає можливість використання як приймачів ІЧ випромінювання піроелектричних детекторів, що мають кращі характеристики в порівнянні 3 іншими типами приймачів [14].

Смуга пропускання оптоволоконних світловодів, що з'єднують лінзові комплекти з входами приймачів ІЧ випромінювання, має бути узгоджена або зі смугою пропускання лінзових комплектів, або (в загальному випадку) зі смугою частотного спектра випромінювання нормально нагрітих та аварійних буксових вузлів у діапазоні температур зовнішнього повітря $-40^{\circ} \mathrm{C} \ldots+50^{\circ} \mathrm{C}$. Враховуючи, що надлишкова температура зовнішніх поверхонь корпусів нормально нагрітих букс становить близько $20^{\circ} \mathrm{C}$, а несправних $38^{\circ} \ldots 42^{\circ}$ (мін), фактичний діапазон температур букс, що можуть перебувати в зоні контролю, становить $-20^{\circ} \mathrm{C} \ldots+100^{\circ}$ С. Спектральну випромінювальну 
здатність об’ єктів контролю з такими температурними характеристиками розрахуємо за допомогою формули Планка [16].

$f(\omega, T)=\frac{\eta \omega^{3}}{4 \pi^{2} c^{2}} \frac{1}{e^{\eta \omega / k T}-1}$.

Якщо від кутової частоти перейти до довжин хвиль, вираз (1) набуде вигляду:

$\varphi(\lambda, T)=\frac{4 \pi^{2} c^{2} \eta}{\lambda^{5}} \frac{1}{e^{2 \pi c \eta / k T \lambda}-1}$

де $c$ - швидкість світла;

$\lambda$ - довжина хвилі;

$\hbar$ - стала Планка (для кутової частоти);

$k$ - стала Больцмана;

$T$ - температура буксового вузла, К.

Зробивши підстановки у формулу (2) $\mathrm{C} 1=4 \pi \mathrm{c}^{2} \mathrm{~h}=$ $3,7415 \cdot 10^{-16} \mathrm{BT} / \mathrm{M}^{2}$ і $\mathrm{C} 2=2 \pi \mathrm{c} \mathrm{h} / \mathrm{k}=1,4388 \cdot 10^{-2} \mathrm{M} \cdot \mathrm{K}$, розрахуємо за формулою (3) значення функції $f(\lambda, T)$ для буксових вузлів 3 температурами $-20^{\circ} \mathrm{C}(293 \mathrm{~K})$, $100^{\circ} \mathrm{C}(473 \mathrm{~K}), 40^{\circ} \mathrm{C}(313 \mathrm{~K})$ як найбільш характерних для визначеного вище діапазону температур: $f(\lambda, T)=\frac{C 1}{\lambda^{5}} \frac{1}{e^{C 2 / T \lambda}-1}$.

Результати розрахунку наведені на графіках, поданих на рис. 1.

Розрахунок проводився для випадку, що випромінювач - абсолютно чорне тіло. Оскільки буксові вузли не $\epsilon$ абсолютно чорним тілом, амплітудні значення спектральної випромінювальної здатності реальних букс будуть меншими у порівнянні 3 розрахунковими на величину коефіцієнта чорноти (0.92...0.96), але спектральний склад випромінювання букс не буде відрізнятись від спектра абсолютно чорного тіла [16].

Згідно із законом зсуву Віна $(T \cdot \lambda \max =b$, де $b=2,910^{-3}$ мК) максимум випромінювальної здатності букс 3 температурою $+100^{\circ} \mathrm{C}$ припадає на випромінювання 3 довжиною хвилі 6,13 мкм, $+40^{\circ} \mathrm{C}-$ 9,26 мкм, $-20^{\circ} \mathrm{C}-11,46$ мкм.

Аналіз графіків 1 - 3 (рис. 1) дає підстави стверджувати, що в загальному випадку смуга пропускання оптоволоконних світловодів, що з'єднують лінзові комплекти з ІЧ приймачами, має перебувати у діапазоні $1,5 \cdot 10^{13}$ Гц...15·10 ${ }^{13}$ Гц, тобто пропускати випромінювання 3 довжинами хвиль від 2 мкм до 20 мкм.

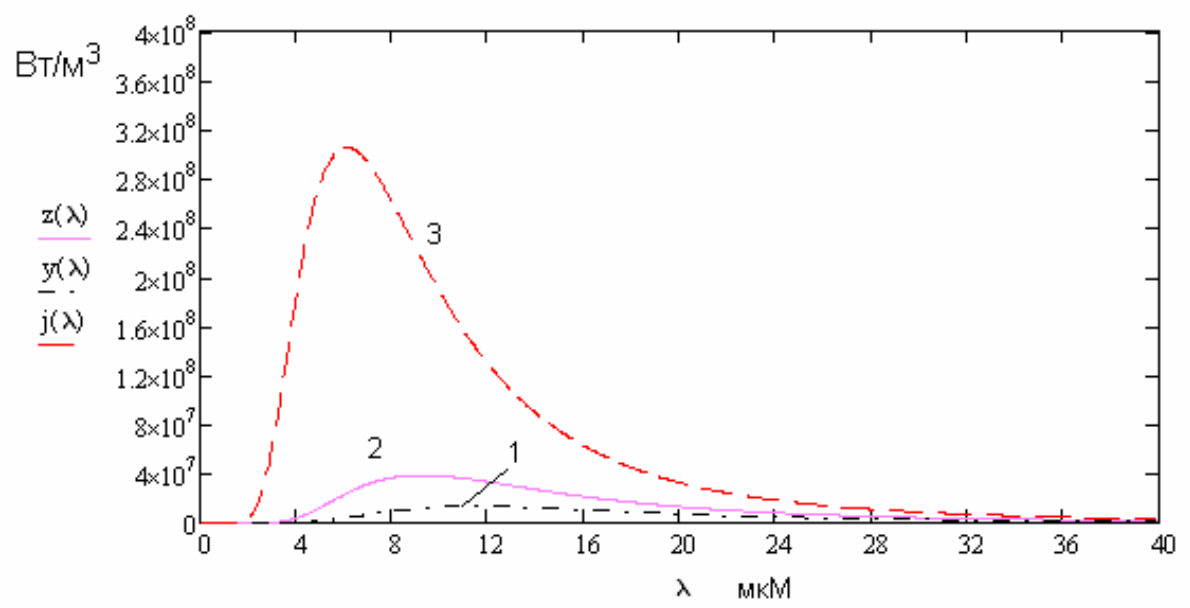

Рис. 1. Спектральна випромінювальна здатність випромінювача 3 температурою нагріву $-20^{\circ} \mathrm{C}$ (кр. 1), $+40^{\circ} \mathrm{C}$ (кр. 2), $+100^{\circ} \mathrm{C}$ (кр. 3)

Блок-схему системи, що пропонується, наведено на рис. 2. Система містить датчик наявності потяга на контрольній ділянці 1, датчики фіксації проходу колісних пар 2, 3, 4 для стробування зон контролю буксових вузлів, підрахунку осей, підрахунку фізичних одиниць i визначення швидкості руху рухомого складу, розміщені 3 обох боків рейкової колії прирейкові камери 5,6 із заслінками 16, що перекривають вхідне вікно 18 за відсутності потяга в зоні контролю, пристроями калібрування каналів вимірювання 17, вузлом управління заслінкою 19, N лінзовими комплектами лк1-лкN, прозорі для IЧ випромінювання оптоволоконні світловоди, постове обладнання 7, що містить $\mathrm{N} * \mathrm{k}$ приймачів IЧ випромінювання прм1-прм $(\mathrm{N} * \kappa)$ (де $\mathrm{N}-$ кількість лінзових комплектів у складі однієї прирейкової 
камери, k - кількість прирейкових камер), електронні (мікропроцесорні) пристрої управління i обробки сигналів приймачів ІЧ випромінювання 13 , джерела живлення 11, технологічний пульт 9 для налаштування постових і прирейкових пристроїв, ручного управління процесом калібрування вимірювальних трактів, датчик температури повітря 8. Управління заслінками 16 i калібраторами 17, а також передавання контрольної інформації від вузлів калібраторів до постових пристроїв здійснюється за допомогою кабелю 15.
Зв'язок між постовими і станційними пристроями здійснюється за допомогою модемів 10 лінією зв'язку Л3. Як устаткування для аналізу i реєстрації результатів контролю - автоматизованого робочого місця (АРМ ЛПК) використовуються персональні EOM 12 із спеціалізованим прикладним програмним забезпеченням, що формує за результатами аналізу теплових сигналів комплексну картину розподілу температур нагріву контрольованих поверхонь i визначає стан буксових підшипників.
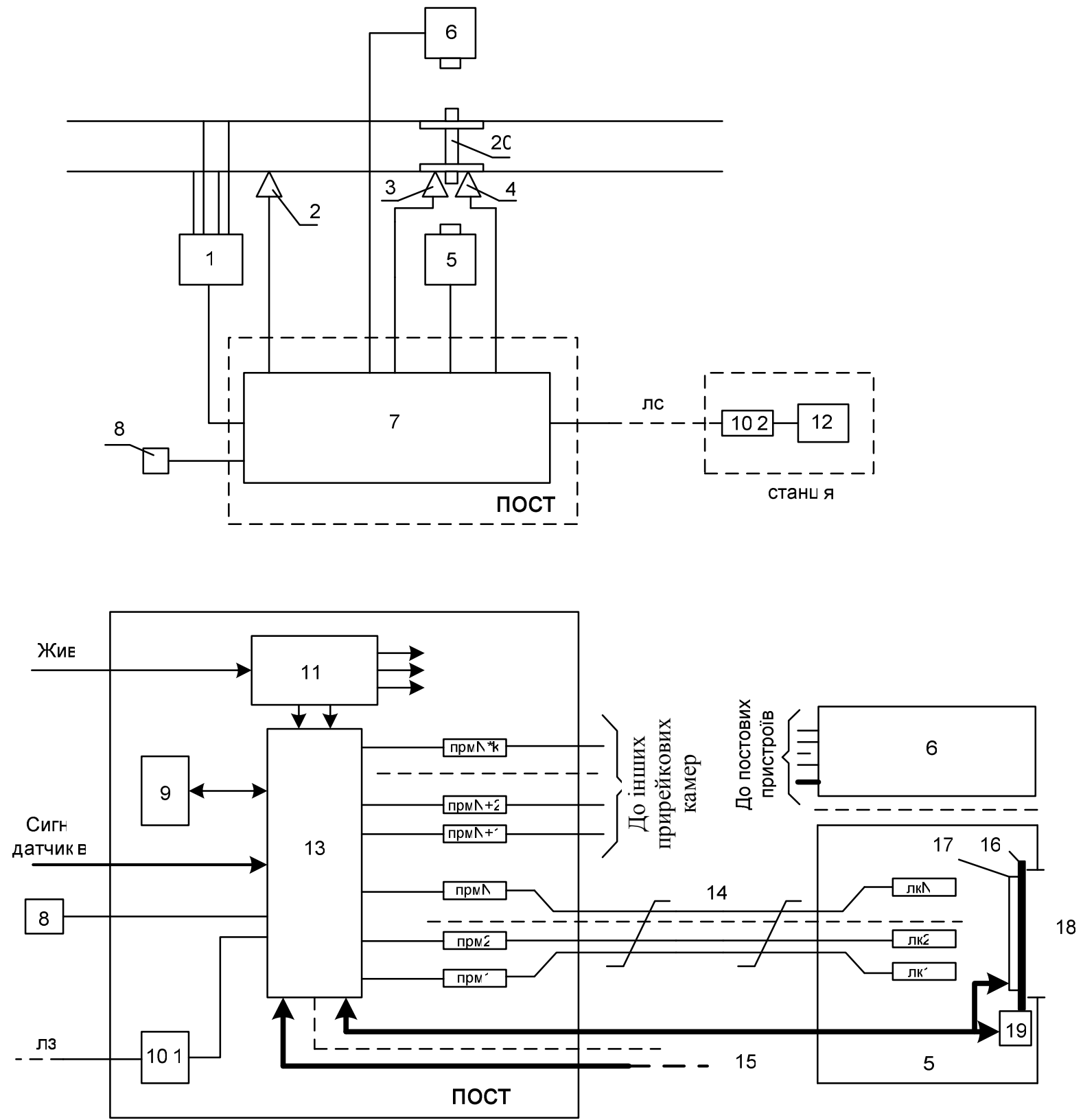

Рис. 2. Система теплового контролю буксових вузлів рухомого складу 


\begin{abstract}
Висновки
Впровадження запропонованої системи дасть змогу підвищити ефективність контролю ходових частин потягів за рахунок використання декількох каналів вимірювання для контролю кожного буксового вузла і введення в систему більш повної початкової інформації, на підставі якої приймається рішення про фактичний стан буксових підшипників. Одночасне використання декількох каналів вимірювання знижує вірогідність пропуску перегрітих букс при повних або часткових відмовах (відхиленні параметрів) елементів окремих каналів. Розміщення приймачів IЧ випромінювання в умовах поста послаблює вимоги до ix розмірів, конструктивного оформлення, полегшує оптимізацію температурних режимів роботи і сприяє підвищенню точності вимірювання температури контрольованої поверхні/поверхонь. Оскільки в умовах поста рівень динамічних i акустичних навантажень істотно нижчий, ніж в умовах прирейкової камери, створюються передумови використання як приймачів ІЧ випромінювання піроелектричних детекторів, що мають кращі характеристики в порівнянні 3 іншими типами приймачів.
\end{abstract}

\section{Список використаних джерел}

1. Аналіз стану безпеки руху на залізницях України у 2017 році [Текст] / Міністерство інфраструктури України. Публічне акціонерне товариство «Українська залізниця». Департамент безпеки руху. - К., 2018. - 41 с.

2. Анализ опыта эксплуатации технических средств контроля ходовых частей подвижного состава в движущихся поездах [Текст] / А. А. Миронов, В. Л. Образцов, В. Я. Соболев, К. В. Григорьев // Автоматика, связь, информатика. - 2005. - № 3. C. $28-30$.

3. Schobel, A. Betrieb und Verkehr Optimierungspotenziale bei der Stationierung von Heisslauferortungsanlagen [Text] / A. Schobel, J. Karner // Eisenbahntechnische Rundshau ETR. 2005. - № 12. - P. 805-808.

4. Eisenbrand, E. Phönix MB - die neue Heißlaufenortunganlage [Text] / E. Eisenbrand // Signal\&Draht. - 1998. - № 12. - P. 9-11.

5. Павлюков, А. Э. Диагностическая модель теплового контроля букс подвижного состава [Текст] / А. Э. Павлюков, А. А. Миронов, А. В. Занкович // Транспорт Урала. - 2004. - № 2. - C. 44-52.

6. Lunus, O. Investigation on features and tendencies of axle-box heating [Text] / O. Lunys, S. Dailydka, G. Bureika // Transport problems. - 2015. - № 10. P. 10-114.

7. Schobel, A. Hot box detection systems as part of automated train observation in austria [Text] /
A. Schobel, M. Pisek, J. Karner // Towards the competitive rail systems in Europe. - 2006. P. 157-161.

8. Eisenbrand, E. Hot box detection in European railway networks [Text] // RTR Special. - 2011. - P. 2-11.

9. Регеда, В. В. Анализ методов контроля букс грузовых вагонов на ходу поезда [Текст] / В. В. Регеда, В. М. Петухов // Зб. наук. праць. Харків : УкрДАЗТ, 2007. - Вип. 84. - Ч. 3. C. 94-98.

10. Виммер, Й. Новое поколение устройств обнаружения греющихся букс и заклиненных колес [Текст] / Й. Виммер // Железные дороги мира. - 2000. - № 1. - С. 24-29.

11. Миронов, А. А. Технические средства диагностики ходовых частей подвижного состава [Текст] / А. А, Миронов, В. Л. Образцов, А. Э. Павлюков // Вагоны и вагонное хозяйство (Приложение к журналу "Локомотив"). - 2005. - № 2. - С. 42-46.

12. Способ и система для измерения температуры нагрева оси и подшипникового узла. Process and system for measuring axle and bearing temperatures [Текст] : пат. 5201483 США (US) МКИ 5 B61 L 3/06. / Inventor(s): Sutnar; Ivan, Leoben, Austria, Nayer; Wolfgang, Zweltweg, Austria. Applicant(s): Voest-Alpine Eisenbahnsysteme Gesellschaft m. b. H., Vienna, Austria. - Опубл. 13.04.93.

13. Система теплового контролю буксових вузлів рухомого складу [Текст] : пат. 117379 С2 Україна / МПК (2018.01), В61К 9/06 (2006.01), B61L 27/00; заявл. 01.04.2016; опубл. 25.07.2018, Бюл. № 14.

14. Прибор на основе пироэлектрического приемника ИК излучения для дистанционного измерения температуры буксовых узлов рельсового транспорта в процессе движения [Текст] / В. В. Рыбак, С. К. Скляренко, А. А. Строкач // Наука та інновації. - 2007. - Т. 3, № 2. - С. 34-47.

15. Концепція побудови комплексної системи визначення технічного стану рухомого складу: напільні пристрої[Текст] / I. М. Сіроклин, В. П. Мороз, В. М. Петухов, А. О. Каргін // Залізничний транспорт України, 2018. - № 2. C. 13-21.

16. Рембеза, Е. С. Квантовая, атомная и ядерная физика: курс лекций [Текст]: учеб. пособие / Е. С. Рембеза, В. С. Железный, Е. А. Косякова. Воронеж : ФГБОУ ВПО «Воронежский государственный технический университет», 2011. $-135 \mathrm{c}$.

Мартынов И. Э., Нейчев О. В., Сосунов А. А., Петухов В. М., Труфанова А. В. Система теплового контроля буксовых узлов подвижного состава. Представлена система теплового контроля буксовых узлов подвижного состава, которая способна существенно повысить эффективность контроля 
ходовых частей вагонов и локомотивов за счет использования нескольких каналов измерения температуры каждого буксового узла, ступиц колес и ввода в систему более полной исходной информации, на основании которой принимается решение о фактическом состоянии буксовых подшипников.

Ключевые слова: система контроля состояния буксовых узлов подвижного состава, система диагностирования подвижного состава, тепловой контроль буксовых узлов.

Martynov I.E., Nejchev O.V., Sosunov A.A., Petukhov V.M., Trufanova A.V. Thermal checking hot box system knots of rolling stock. One of the most responsible elements of construction of freight carriage, that directly influence on safety of motion, hot box knots are with bearing of that or other type. Therefore to development and perfection of apparatus facilities and methods of control of hot box knots, especially in the process of motion, considerable attention is spared.

On the railways of Ukraine the systems of the noncontact diagnosticating are used, that after the level of heating of external surfaces of hot box knots and disks of wheels allow to define the state of the hot box bearing. The lack of the systems of diagnostics of similar type is that the scan-out of axle-bearing comes true by the single narrowly directed transceiver of infrared by a difficult spatial trajectory. From that, what zones of axle-bearing corps will get in a keepout and under what corner, the powerlevel of radiation that is accepted, and level of signal, on the basis of that made decision about the temperature of bearing, depends, accordingly. Therefore even the insignificant exit of veritable trajectory of scan-out on other surface of axle-bearing corps results in forming of inexact or erroneous signal. In addition, the general lack of all well-known systems of diagnostics of hot box knots of rolling stock is absence of backuping of devices of the system, including those the improper functioning of that can result in dangerous refuses - admissions of the emergency axle-bearing.

With an aim the removal of the defects listed above is offered system of diagnostics of hot box knots of rolling stock, that is able to control the temperature of heating of a few points of external surfaces of corps of axle-bearing and other knots from every side of train, and to form the complex picture of distribution of temperatures of heating of the controlled surface (surfaces). Such possibility arises up as a result of dispersal of elements/of devices of apparatus of transceivers-strengtheners of every measuring channel. In an offer system floor chambers contain for $\mathrm{N}$ of the lens complete sets of receiving optics, united by means of transparent for an infrared optical light-pipes with the transceivers of infrared. The transceivers of infrared are situated thus on a post. Id est, in floor chambers lens complete sets are set only with the elements of fastening, and got by them in the process of control a "useful" signal comes to the transceivers-transformers optical light-pipes.

Placing of transceivers of infrared in the conditions of post weakens requirements to their sizes, structural registration, facilitates optimization of temperature conditions of work and assists the increase of exactness of measuring of temperature of the controlled surface. As in the conditions of post the level of the dynamic and acoustic loading substantially below, than in the conditions of floor chamber, possibility of using appears as transceivers of radiation of detectors that have the best descriptions as compared to other types of transceivers.

Keywords: checking of the state of hot box knots of rolling stock system, system of diagnosticating of rolling stock, thermal control of hot box knots.

Надійшла 18.09.2018 p.

Мартинов Ігор Ернстович, доктор технічних наук, професор кафедри «Вагони» Українського держсавного університету залізничного транспорту, Харків, Україна. E-mail: martinov.hiit@gmail.com, ORCID ID: https://orcid.org/0000-0002-0481-3514

Нейчев Олег Володимирович, кандидат технічних наук, доиент кафедри «Автоматика та комп'ютерне телекерування рухом поӥздів» Украӥнського державного університету залізничного транспорту, Харків, Україна. E-mail: khnow1963@ukr.net, ORCID ID: https://orcid.org/0000-0002-9093-0804

Сосунов Олександр Олексійович, кандидат технічних наук, дочент кафедри "Автоматика та комп'ютерне телекерування рухом поӥздів» Украӥнського державного університету залізничного транспорту. E-mail: $\quad$ sosunov63@kart.edu.ua, ORCID ID: https://orcid.org/0000-0003-2175-7363

Петухов Вадим Михайлович, кандидат технічних наук, доцент кафедри «Вагони» Украӥнського державного університету залізничного транспорту, Харків, Україна. E-mail: hiitwagen@gmail.com, ORCID ID: https://orcid.org/0000-0003-4781-9956

Труфанова Алена Володимирівна, канд. техн. наук, дочент кафедри «Вагони» Украӥнського державного університету залізничного транспорту, Харків, Україна. E-mail: alena.hiit.vagons@gmail.com, ORCID ID: https://orcid.org/0000-0003-1702-1054

Martynov Igor Ernstovych, doctor of technical sciences, professor of department is "Carriages" of the Ukrainian state university of railway transport, Kharkiv, Ukraine. E-mail: $\quad$ martinov.hiit@gmail.com, ORCID ID: https://orcid.org/0000-0002-0481-3514

Nejchev Oleh Vladimirovich, candidate of technical sciences, associate professor of department of "Automat 
І Н Ф О Р М АЦ І Й Н О - КЕ Р У Ю Ч І С И С Т Е М И Н А 3 А Л І 3 Н И Ч Н О М У Т Р А Н С П О Р Т І

and computer telecontrol by motion of trains" of the Ukrainian state university of railway transport, Kharkiv, Ukraine. E-mail: khnow_1963@ukr.net, ORCID ID: https://orcid.org/0000-0002-9093-0804

Sosunov Aleksandr Alekseevich, candidate of technical sciences, associate professor of department of "Automat and computer telecontrol by motion of trains" of the Ukrainian state university of railway transport, Kharkiv, Ukraine. E-mail: sosunov63@kart.edu.ua, ORCID ID: https://orcid.org/0000-0003-2175-7363

Petukhov Vadim Mykhaylovych, candidate of technical sciences, associate professor of department is "Carriages" of the Ukrainian state university of railway transport, Kharkiv, Ukraine. E-mail hiitwagen@gmail.com, ORCID ID: https://orcid.org/0000-0003-4781-9956

Trufanova Alena Vladimirovna, candidate of technical sciences, associate professor of department is "Carriages" of the Ukrainian state university of railway transport, Kharkiv, Ukraine. E-mail: alena.hiit.vagons@gmail.com, ORCID ID: https://orcid.org/0000-0003-1702-1054 